\title{
The Study of Renaissance and Reformation Books on the Canadian Prairies
}

\author{
DAVID WATT \\ St. John's College, University of Manitoba \\ SHARON WRIGHT \\ St. Thomas More College, University of Saskatchewan \\ PAUL DYCK \\ Canadian Mennonite University
}

\begin{abstract}
This article begins by providing a survey of collections holding Renaissance and Reformation books in Saskatchewan and Manitoba in order to draw attention to the range of resources across the prairies. The article's second section focuses on the manuscripts and rare books at the University of Manitoba in order to highlight the research opportunities afforded by individual collections and the potential benefits of exploring them in aggregate. Taken together, the collections described here-from the bibles donated by Rev. Greatorex to St. John's College in 1897 to the remarkable collection of early books at Notre Dame College in Wilcox, Saskatchewan-can help us to consider questions about the cultural and physical place of books in Reformation and Renaissance studies as well as questions about the significance of their place on the prairies.
\end{abstract}

Cet article recense d'abord les collections incluant des livres de la Renaissance et de la Réforme en Saskatchewan et au Manitoba, afin d'attirer l'attention sur les ressources dans ce domaine présentes dans les prairies canadiennes. Dans un second temps, on s'y concentre sur les manuscrits et les livres rares conservés à l'Université du Manitoba dans le but de mettre en lumière les opportunités de recherches que représentent les collections individuelles ainsi que le potentiel de les examiner dans leur ensemble. En effet, prises dans leur ensemble, les collections décrites - des bibles données par le révérend Greatorex du collège St. John en 1897 à la remarquable collection de livres anciens et d'incunables du collège Notre-Dame de Wilcox en Saskatchewan - permettent d'approcher des questions au sujet de la culture et de la répartition géographique des livres relevant des études de la Renaissance et de la Réforme, et mieux comprendre les raisons et causes de leur répartition dans les prairies.

\footnotetext{
ccording to the English translation of the Ship of Fools printed in 1570, the first fool aboard the ship takes great pleasure in the luxury and quantity of his books, yet he grows to despise them because he fails to learn the wisdom they have to offer:
} 
I am the first foole of all the whole nauie,

To keepe the Pompe, the Helme and eke the Sayle:

For this is my minde, this one pleasure haue I,

Of bookes to haue great plentie and apparayle.

I take no wisedome by them, nor yet auayle,

Nor them perceaue not, and then I them despise:

Thus am I a foole, and all that sue that guise. ${ }^{1}$

He earns his place as the first of the fools because he misunderstands the proper place of books. The pleasure he takes from books derives from possessing them physically rather than intellectually:

Lo in likewise of bookes I haue store,

But fewe I reade, and fewer understande,

I folowe not their doctrine nor their lore,

It is ynough to beare a booke in hande. ${ }^{2}$

This fool, who collects books without understanding what they mean, provides an apt point of departure for this article. On the one hand, he describes practices that most of us would want to leave behind as quickly as possible. On the other hand, his appearance in Winnipeg provides a good starting place for those who wish to avoid, in his words, "su[ing] that guise." The passage cited here is drawn from Alexander Barclay's English translation of The Ship of Fools printed by John Cawood in 1570 (Dysart 24) and now held at the University of Manitoba. In this book, Barclay's translation is bound alongside its source text, Jakob Locher's Stultifera nauis, which is itself a translation of Sebastian Brant's Das Narrenschiff. In addition to the copy of Stultifera nauis that appears in Dysart 24, the University of Manitoba holds two earlier editions of Locher's Latin translation (Dysart 22 was published in 1494; Dysart 23 was published in Basel in 1572). All three books (preserving four translations of Brant's Das Narrenschiff in total) are part of the Dysart Collection, which is one part of the manuscript and rare book holdings at the University of Manitoba; these, in turn, are part

1. Sebastian Brant, The Ship of Fooles, wherein is showed the folly of all states, with divers other workes adioyned unto the same, very profitable and fruitfull for all men, trans. Alexander Barclay (London: 1570), fol. Alv. Winnipeg, MB, Archives \& Special Collections, University of Manitoba, Dysart 24.

2. Brant, fol. A2 $2^{\mathrm{r}}$. 
of a larger resource of similar books in collections across the prairies. The message conveyed by these translations and their appearance in early printed books in Winnipeg seems clear: it would be foolish indeed not to attempt to learn something from the "great plentie" of manuscripts and rare books in these collections, from the bibles donated by Rev. Greatorex to St. John's College in 1897 to the remarkable collection of early books at Notre Dame College in Wilcox, Saskatchewan; together, they can help us to understand the place of Renaissance and Reformation books historically.

This article aims to provide an overview of the books on the prairies and an indication of the potential for future studies of the books and their significance. It begins by surveying some places in Saskatchewan and Manitoba where manuscripts and rare books can be found. This survey is designed to invite scholars to learn more about these substantial collections and to imagine how manuscripts and rare books on the Canadian prairies might be used to explore the place of books in the Renaissance and Reformation. The article's second section focuses on the manuscripts and rare books held at University of Manitoba in order to suggest several other ways in which prairie collections, individually or in aggregate, might help us to understand the place of these books historically. First, it explores questions about why and how many of these books came to Winnipeg, arguing that to understand these books historically, we must understand how they came to be in this place and what they might mean today. It then focuses on the way that the University of Manitoba's collection can be used to explain the ongoing place of manuscripts in Renaissance and Reformation culture, sometimes as independent entities and sometimes as material used to supplement either the content or the physical structure of printed books (especially the binding). This section closes by considering more traditional ways in which these substantial collections, individually and in aggregate, can help us to understand the cultural place of books in the Renaissance and Reformation. The article as a whole concludes by looking to current and future projects designed to encourage new scholars and scholarship focused on the study of the book on the Canadian prairies, including the history of individual book copies as well as the collections in which they now find their place. ${ }^{3}$ 


\section{The place of books on the Canadian prairies}

This section provides an overview of collections in Saskatchewan and Manitoba that may be of particular interest to those studying Renaissance and Reformation books. It does not provide an exhaustive list of holdings in these provinces. Instead, it reflects those collections where this article's authors have begun developing a project under the titles Mapping the Pages and Maple Leaves: The Study of Manuscripts and Early Printed Books in Western Canada. This project aims to identify, record, and track the journey and contents of uncatalogued manuscripts and early printed books in public and private collections. Its ultimate goal is to support scholarship further by providing a more comprehensive integrated catalogue of books held throughout the region. The two titles will include the collections discussed here as well as others, including those at Brandon University; the Universities of Alberta, ${ }^{4}$ Calgary, Regina, and Winnipeg; and the Winnipeg Art Gallery. The project will also look beyond institutional collections, which can only tell part of the story of books on the Canadian prairies. The focus of Mapping the Pages in particular is to reconstruct the reading list of prairie settlers from the earliest days of European settlement as well as to preserve a part of prairie history that is ephemeral and threatened by the closures and centralizations of religious orders, the lack of space in public libraries, and the destruction of private collections. As our old books disappear from private libraries and attics, so do our opportunities to study the history of our printed companions and their influence upon prairie readers and communities. Perhaps the most important aspect of our research is to identify, preserve, and make known our hidden treasures. For this we require the help of prairie people, like the man who came to the Canadian Mennonite University (CMU) to show Dr. Paul Dyck his old family bible which, as it happens, was an early seventeenth-century Geneva Bible that had been brought by the family to Saskatchewan around 1900 and then on to Winnipeg. This is just one example of the relationship between historical books and prairie histories that this project is hoping to uncover and identify. Books such as this first formed and continue to inform the intellectual, cultural, and spiritual library of prairie people. Anticipating that the collections will continue

4. The Bruce Peel Special Collections Library at the University of Alberta has an informative web page: "Bruce Peel Special Collections Library-Major Holdings," 16 March 2014, http://www.library.ualberta. $\mathrm{ca} /$ specialcollections/major/index.cfm. 
to change-forever deferring the completion of a catalogue or archive-this article offers both an overview and evidence that will enable critical arguments about the bibliographical and cultural value of these books.

\section{Saskatchewan}

\section{The Bietenholz Rare Book Collection}

In 2009, Doris Bietenholz, author and philanthropist, and Dr. Peter Bietenholz, emeritus professor of Renaissance history, gifted their private collection of rare books to the University of Saskatchewan in celebration of their fiftieth wedding anniversary. They also made significant donations to the U of S's Museum of Antiquities. The majority of the Bietenholz collection of early printed books were purchased in Basel, where the Swiss-Canadian couple maintained a small home. The ninety-eight volumes date from 1514 to 1860 with the majority dating to the sixteenth and seventeenth centuries and containing works of literature, philosophy, and theology. They have been partially digitized by Special Collections at the $\mathrm{U}$ of $\mathrm{S}$.

\section{Father Athol Murray Rare Book Collection}

Fr. Murray's (1892-1975) remarkable book collection, now stored in the archives at Athol Murray College of Notre Dame in Wilcox Saskatchewan, contains six incunables, including a Nuremburg Chronicle, and a large number of sixteenth-century books (226 volumes in total in addition to a small selection of medieval manuscripts). ${ }^{5}$ The printed book collection dates from 1483 to 1922 and consists of theological, historical, philosophical, and literary works, including many books donated by Robert E. Lee's granddaughter who was a childhood friend of Murray. The collection includes several medieval manuscripts apparently gifted or purchased from the Vatican. The manuscripts are currently being studied, catalogued, and digitized by Dr. Sharon Wright, St. Thomas More College, for Mapping the Pages. ${ }^{6}$ The Nuremburg Chronicle

\footnotetext{
5. For an overview of this collection's public appeal, see Mark Abley, "The Wilcox Manuscripts," The Walrus(December/January2005), http://walrusmagazine.com/articles/2005.01-field-notes-Saskatchewanhistory/2/.

6. See also Michael Santer, "A Descriptive Catalogue of Rare Books in the Library of Notre Dame College, Wilcox, Saskatchewan" (master's thesis, University of Saskatchewan, 2003).
} 
and other manuscripts can be viewed on the webpage she has created for the project. $^{7}$

\section{Shannon Library, St. Thomas More College}

The Shannon Library contains a small collection of rare first-edition and early reprinted works by St. Thomas More, including one of the six extant 1518 editions of Utopia. Special Collections has more than fifty early printed books dating from 1517, most theological or didactic in nature, that came to the college from teaching collections formerly held by monastic communities.

\section{Theological Union Libraries, University of Saskatchewan}

The Theological Union Libraries contain roughly two dozen rare theological books dating from the mid-sixteenth century. Contact the librarian for more information.

\section{Manitoba}

\section{Walter Loewen Collection}

This collection was donated to CMU in 2003 by Walter Loewen, who was in the music business and personally collected these materials. The Loewen Collection includes four complete books, part of a fifth, and a range of loose sheets. The materials are predominantly Spanish, musical, and manuscript. Two of the books, Loewen MSS 1 and 5, are antiphonaries. Both books are striking for their size: Loewen 5, a sixteenth-century book, measures a substantial $860 \mathrm{~mm}$ x $595 \mathrm{~mm}$; it contains just over one hundred parchment leaves and includes chants for the Offices from Easter to Corpus Christi. This book also includes many illuminated capitals: these often include floral motifs as well as particular symbols, such as a dog carrying a torch, marking the book as belonging to the Dominican Order. Among the many chants found in this volume is the familiar Pentecost hymn, Veni creator spiritus, still found in many of today's hymnals. Other books include a manuscript Liturgy for the Office of the Veil with Spanish rubrics (Loewen MS 2) and a Processional printed in 1536 that includes staff 
lines in red and text and notation in black (Loewen MS 3). The loose sheets in the collection range from the thirteenth to the nineteenth century. Since they are predominantly musical, they offer insights into transformations in letter forms and musical notation as well as production techniques. Each aspect of this collection, from its individual book copies to the relationship between its donor's personal interests and those of the institution to which he bequeathed the books, can be understood more fully when considered in its place among other prairie collections.

\section{St. John's College Collection}

St. John's College owns one manuscript, several fragments (four in frames and several in or on other books), one incunable, and many books printed in the sixteenth and seventeenth centuries. This collection is largely comprised of bibles and prayer books donated by the Reverend Daniel Greatorex, Vicar of St. Paul's, Whitechapel in London (Figure 1. Bookplate). The St. John's College Collection provides sufficient material for a comprehensive introduction to the history of early printed bibles in English. It includes a first edition of the Matthew's Bible (1537); a second edition of the Great Bible, the version that includes Cramner's introduction (1540); a first edition of the full Geneva Bible (1560); a copy of Tyndale's translation printed by Richard Jugge (1566), a first edition of the Bishops' Bible (1568), an early printing of the Geneva Bible in England (1577); a later, interleaved, copy of the Geneva Bible in four volumes (1606); a first edition of the Authorized (King James) Bible (1611); ${ }^{8}$ and a copy of the New Testament along with William Fulke's defense of the translation of scripture printed for John Bill (1617). There are also a number of bibles in different languages. One of these bibles is the collection's incunable, a Latin Bible printed by Anton Koberger in Nuremberg (1478). ${ }^{9}$ Other bibles include a copy of the New Testament translated into Latin by Erasmus (1562), an interleaved Greek and Latin Bible printed in Geneva (1580), a Greek Septuagint printed

8. For digital access to the King James Bible, see Paul Dyck, Shelley Sweeney, Jason Peters, and David Watt, This Booke of Starres: 400 Years of the King James Bible, 11 March 2014, http://umanitoba.ca/libraries/units/archives/digital/bible/index.html.

9. For a detailed description of this book, see University of Manitoba Libraries, "Biblia Latina," Rare Books \& Manuscript Collections, 11 March 2014, http://www.umanitoba.ca/libraries/archives/collections/type/rarebooks/bison/bis_BibLat1478stj.html. 
by John Field (1665), a Polyglot Bible printed by Thomas Roycroft (1657), and Turkish (1666) and Coptic (1716) Bibles printed in Oxford. The study of these bibles can be supplemented through a study of their relationship to the Book of Common Prayer: one was printed by Richard Jugge (London, 1573) and is bound with the Psalms, which were printed by John Daye (London, 1573); another is a copy of the Book of Common Prayer and psalms printed by Robert Barker (London, 1607) and bound with another bible printed by Barker (London, 1607) as well as psalms printed by W. S. (1631). The collection also includes several seventeenth-century historical and theological books, including works by John Pearson, Bishop of Chester; ${ }^{10}$ Edward Stillingfleet, Bishop of Worcester; ${ }^{11}$ and William Cave. ${ }^{12}$ Overall, the St. John's College Collection is especially helpful for Reformation scholars, though it also provides a rich resource for those studying the place of books in the Renaissance. ${ }^{13}$

\section{The Dysart Memorial Collection}

The Dysart Memorial Collection includes nine manuscripts, sixteen incunabula, and forty-four other printed books. This collection has typically been considered separately from other manuscripts and rare books held at University of Manitoba. This state of affairs inaccurately represents the way these books were acquired, though it accurately describes the way their acquisition was funded. The money to purchase the collection was provided by the Manitoba Brewers' and Hotelmen's Welfare Fund “in memory of the late Mr. Justice Dysart, who

10. John Pearson, An Exposition of the Creed (London: 1662).

11. Edward Stillingfleet, A rational account of the grounds of Protestant religion; being a vindication of the Lord Archbishop of Canterbury's Relation of a conference, etc. from the pretended Answer by T.C. etc. (London: 1665).

12. William Cave, Antiquitates Christianae; or, the history of the life and death of the Holy Jesus: as also the lives, acts \& martyrdoms of his apostles (London: 1678); Apostolici: or, the history of the lives, acts, death, and martyrdoms of those who were contemporary with, or immediately succeeded the apostles (London: 1677); and Ecclesiastici: or, the history of the lives, acts, death, and writings, of the most eminent Fathers of the Church, that flourisht in the fourth century (London: 1683).

13. The bibles themselves are, of course, Renaissance books, but several others also merit attention: an early printed edition of Boethius's Consolation of Philosophy (1501); Erasmus's De recta Latini Graecique sermonis pronuntiatione (1531) as well as his paraphrase of Matthew, In evangelium Matthaei (1544), and another English translation of all of Erasmus's paraphrases of the New Testament (1551-52); and editions of Euclid (1572), Strabo (1620), Terence (1575), and Vergil (1522). 
was Chancellor of the University for many years and Chairman of the Board of Trustees of the Manitoba Brewers' and Hotelmen's Welfare Fund since its inception in 1940." ${ }^{14}$ All but one of the manuscripts in the Dysart Collection are arguably Renaissance productions, having been produced in the fifteenth century or afterwards. These, along with the incunables and rare books, will be discussed in greater detail later in the article. A descriptive catalogue for this collection is available, though it needs to be updated.

\section{Archives \& Special Collections, University of Manitoba}

The Archives \& Special Collections holds two manuscripts other than those that form part of the St. John's College and Dysart Memorial Collections. The first of these, the Pomianyk of Horodysche, was donated to the university by Professor Rudnycknyj on 23 October 1991. This book is "a register of the deceased to be remembered at requiem services" begun in 1484 and compiled from that time until around 1737; it "is the oldest of all dated cyrillic texts" in North America. ${ }^{15}$ The second of these manuscripts is a sixteenth-century diploma donated to the university in 2012 by Betty Braaksma. Most of the other early printed books in the Archives \& Special Collections were purchased at the same time as the Dysart Collection but separated from it for accounting purposes. These 121 "other" books include a large number of literary and religious books printed in the seventeenth and eighteenth centuries: among them are early editions of Addison's works (printed by Baskerville in 1761), several more bibles printed by Barker (who also printed the King James version), various editions of Sir Thomas Browne, a missal from 1578, an Aldine edition of Catullus bound with Juvenal (1601), a copy of James I's Great Seal attached to a general pardon granted to Thomas Wyke of Frant (1604), a second edition of Ben Jonson's works (1640), an issue of the first edition of Paradise Lost printed in 1669, a second folio of Shakespeare's works (1632), early editions of Spenser's Faerie Queene (1609-11) and collected works (1617), editions of Virgil's works from 1529 and 1639, an emblem book (1648), and samples of a

14. Frank G. Mathers to F. W. Crawford, 8 September 1952, box 194-005, President's Papers UA 29, University of Manitoba, Archives \& Special Collections.

15. See University of Manitoba Libraries, "Horodysche Pomianyk," Rare Books and Manuscript Collections, 13 March 2014, http://umanitoba.ca/libraries/archives/collections/type/rarebooks/bison/ bis_slavMss1.html. 
variety of books and printing techniques. These books appear in the library's electronic catalogue, yet few people know about them because they are not clearly differentiated from other books in the collection or, more problematically, other electronic resources that provide digital facsimiles of early books. Furthermore, there is no indication in the current catalogue that these books form part of a coherent collection. The contrast in use between these books and the books in the Dysart Collection is striking, and it justifies our aim to produce a descriptive catalogue: such a tool will not only help scholars to learn where books are available but will also help us to develop our understanding of how and why these books came to be in this place.

\section{Studying the place of books on the prairies: the case of University of Manitoba}

It is our hope that scholars will be able to use the previous section to imagine for themselves and their students how they might study the books held in these collections. This section aims to help this process by exploring how the books held in the Archives \& Special Collections at University of Manitoba might be used to think in a variety of ways about the place of these books on the prairies as well as what they might begin to tell us about the place of books in the Renaissance and Reformation. ${ }^{16}$

The bibles and prayer books in the St. John's College Collection remind us that their place in nineteenth-century prairie culture was much different from what it is today. These books were not simply pleasant "to beare," in the words of Brant's fool, "in hande": they were resources vital to the college's mission. ${ }^{17}$ By the turn of the century, the college library already held many books,

16. These holdings have been exhibited several times. A physical and virtual exhibition called "Old Books, New Science" (December 2013-February 2014) was developed by graduate students under the supervision of David Watt at the University of Manitoba. For the virtual exhibition, see Arthur Anyaduba, Katelyn Dykstra-Dykerman, Kalyn Hazlehurst, Elizabeth-Anne Johnson, Zacharie Montreuil, Erica Pflug, Saleh Saffari, and Petra Smith, Old Books, New Science: The University of Manitoba Archives \& Special Collections Exhibition, 10 March, 2014, http://engl7600.wordpress.com/. To Judge a Book by its Cover (October-November 2008) and Medieval and Early Modern Books in the Archives and Special Collections of the University of Manitoba (April-October 2008) were both curated by David Watt.

17. St. John's College began as a school and theological college and later offered programs in the liberal arts as part of the University of Manitoba. See J. M. Bumstead, St. John's College: Faith and Education in Western Canada (Winnipeg: University of Manitoba Press, 2006), 27-43. 


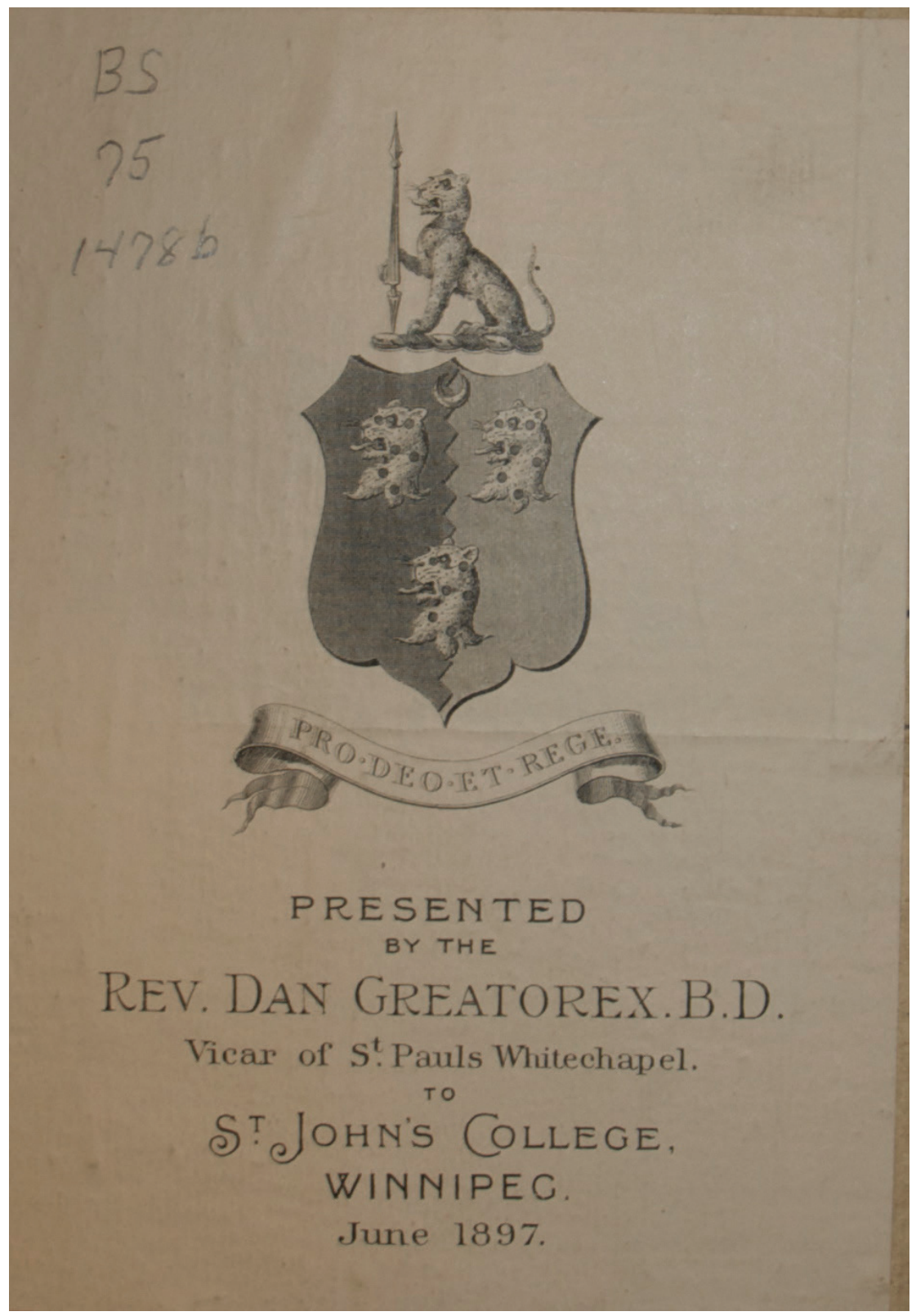

Fig. 1. Bookplate commemorating books donated by Rev. Daniel Greatorex. Reproduced by permission of St. John's College, Winnipeg, Manitoba. 
though they were not always accessible: "one of the continual complaints of the college magazine in these years [1892-1910] was the difficulty of gaining access to the college library...."18 Notwithstanding these problems, the collection grew through a number of key donations. J. M. Bumstead describes how "former student Alexander K. Isbister (Red River Academy, 1833-1837) at his death in 1883 left a bequest to the college of $\$ 83,000$ plus a library of over 4000 volumes." ${ }^{\prime 9}$ These volumes were destroyed by a fire in the McIntyre Block in 1898. However, not all was lost. The books donated by Greatorex survived. Rev. Greatorex travelled to western Canada, in addition to the USA, Australia, and the Middle East, but we have so far not been able to determine why exactly he decided to donate his books to St. John's College. ${ }^{20}$ It seems likely that he felt these books would be put to use in Winnipeg. Greatorex was a great supporter of education, having worked to develop the boys' and girls' schools at St. Paul's, Whitechapel. He was also determined to ensure books were available to a wide range of readers: he developed a ship lending library scheme that provided boxes containing around twenty-five books to ships that could be exchanged each time they returned to port (perhaps with the aim of avoiding literal ships of fools) and he donated a large portion of his collection to the Whitechapel Free Library in 1891. We may never know for certain why Greatorex divided his library donations between his local parish library and a relatively new institution in western Canada. Nonetheless, we have learned and will continue to learn from the books he donated. Several studies and exhibitions have focused either in whole or in part on the 1611 edition of the King James Bible. In his 2009 MA thesis, Jason Peters explored the political and economic factors that contributed to its production and reception in the postReformation culture of early seventeenth-century England by focusing on the Bible as a material book, and he drew much of his comparative evidence from other bibles in the Greatorex collection. ${ }^{21}$ Several exhibitions have used public interest in this particular bible as a way of encouraging audiences to compare and contrast the 1611 Bible with other historical books on the basis of a variety

18. Bumstead, 49.

19. Bumstead, 49.

20. For his travels, see St. George-in-the-East Church, London, "Daniel Greatorex," 19 March 2014, http://www.stgite.org.uk/greatorex.html. We are also grateful to Christine Bone (University of Manitoba) for sharing some of her research into Greatorex's diaries with us.

21. Jason Peters, "The King James Bible and its Readers: Constructing Readable Space in PostReformation England" (master's thesis, University of Manitoba, 2009). 


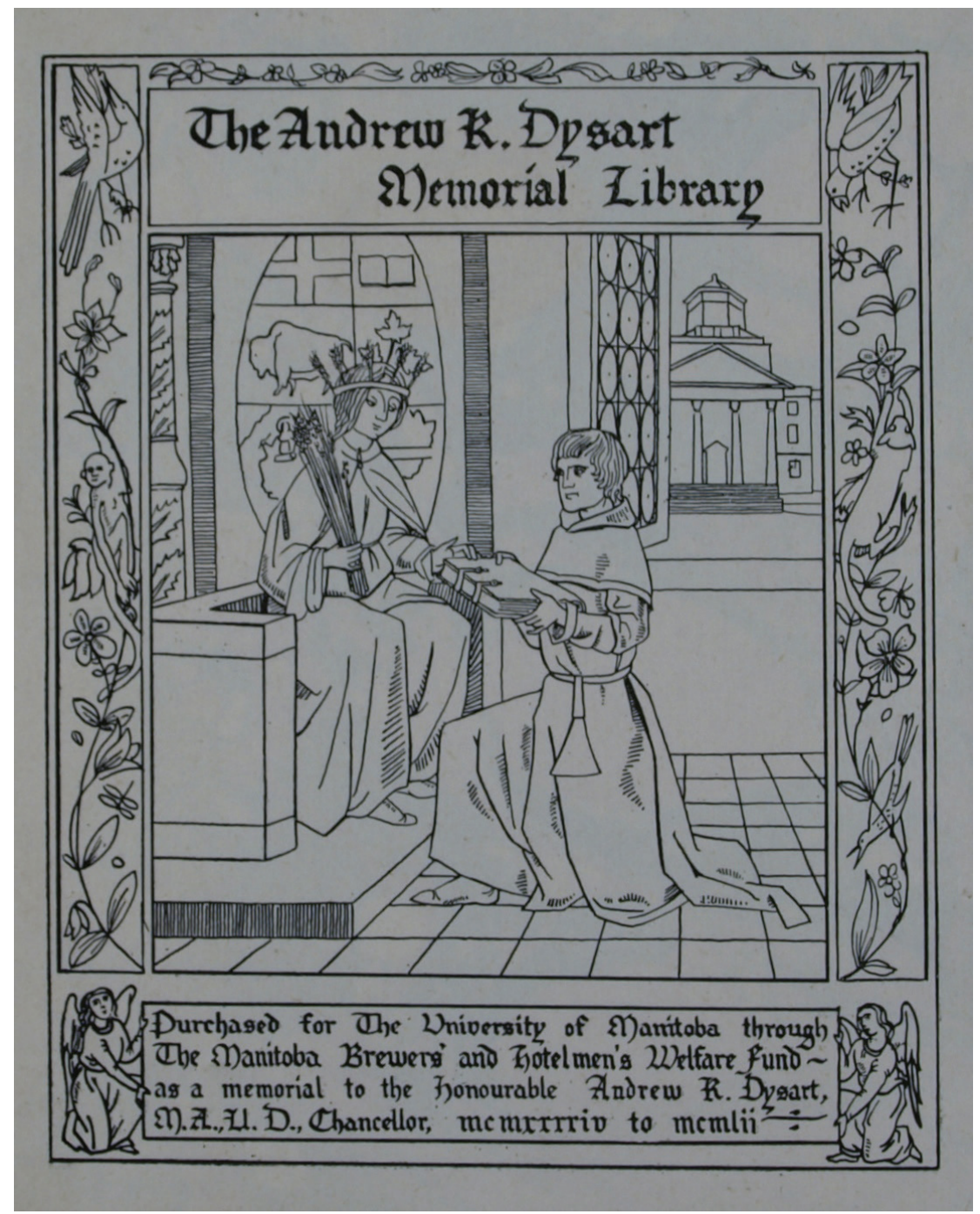

Fig. 2. Bookplate Commemorating the Dysart Memorial Collection. Reproduced with permission of the Archives \& Special Collections, University of Manitoba, Winnipeg, Manitoba. 
of features, including its language, layout, and size..$^{22}$ Moreover, we might also be able to think more critically about other collections on the prairies by comparing them with the books that belonged to Greatorex.

The Dysart Memorial Collection, for example, was assembled for a much different purpose than the Greatorex collection. This collection has typically been considered separately from other manuscripts and rare books held at the University of Manitoba. However, its sixty-nine books should be considered alongside at least 121 other books (mentioned above) that were purchased at the same time and by the same person but were catalogued separately. The bookplate that commemorates this collection (Figure 2) provides great insight into why and how so many manuscripts and rare books are now found in this place as well as why and how the collections were divided as they now are. In the centre of the bookplate, a deferential figure kneels as he presents a clasped book to a crowned figure. This scene alludes to presentation scenes found in medieval and Renaissance books, where writers or scribes are often seen offering their work to their patron or dedicatee. This invocation of a traditional scene encourages readers to see the transfer of books in the context of Western culture. The presented book acts as a metaphor for the process of translatio studii, the transfer of learning and cultural values from one place to another. This idea was invoked historically to describe the transmission of knowledge westwards, from Greece to Rome and then to Western Europe in the medieval period and the Renaissance. It is not hard to imagine why this ideal appealed to scholars in colonial North America, who saw themselves as the next logical destination. ${ }^{23}$ The bookplate for the Dysart Collection embraces this idea by suggesting that a scene taken directly from medieval and Renaissance books can be translated from Europe to the Canadian prairies. It invites readers to imagine not only medieval and Renaissance European culture in this scene but also to imagine the Greco-Roman ideals as being present in this new place. The crowned woman can be identified with the goddess of the harvest, Demeter or Ceres, for she holds sheaves of wheat and wears a crown with wheat in it. This allusion invites readers to imagine the ancient past as part of Manitoba's agricultural present. The scene itself takes place in a room overlooking possibly

22. The most recent exhibition to do this was Dyck, Sweeney, Peters, and Watt, This Booke of Starres.

23. Candace Barrington discusses the idea of translatio studii in colonial North America in American Chaucers, The New Middle Ages (New York: Palgrave Macmillan, 2007). 
the most easily identifiable buildings on campus, one that now serves as the administration building but was once the Manitoba Agricultural College. The building's architectural allusions to Renaissance culture further reinforce the process of translatio studii present in the bookplate while also setting that scene in what is now the entrance to the Elizabeth Dafoe Library, where the Archives \& Special Collections is located. Thus readers are invited to understand this scene to have been enacted in the very place where they might access the books, and to understand the presentation of one book in the scene as a synecdoche for the presentation of the collection as a whole to the library and the collection as a whole as part of a broader narrative about the westward translation of European culture-not to mention some of its valuable artifacts.

While grand narratives about translatio studii explain why someone might attempt to acquire manuscripts and early printed books, these particular books came to Winnipeg because a particular person took action to buy them. The books stayed because others agreed to pay for them. The Dysart Collection bookplate provides very clear information about who footed the bill. In September 1952, the Manitoba Brewers' and Hotelmen's Welfare Fund donated \$10,000 "to purchase rare books for the University of Manitoba library in memory of the late Mr. Justice Dysart."24 The bookplate announces Andrew R. Dysart's role as chancellor of the University from 1944 to 1952, though it curiously fails to mention the fact that he was also chair of the Manitoba Brewers' and Hotelmen's Welfare Fund from 1940 until his death. This connection was obviously crucial in securing the donation, and it reminds us of the role that finances and local networks always play in the creation of books and libraries. The bookplate may also more subtly acknowledge the man who was responsible for the purchasing the manuscripts and rare books that comprise the Dysart Collection. It would be fitting if whoever was responsible for creating the bookplate had Dr. Albert Henry S. Gillson's angular features and dark brows in mind when drawing the face of the kneeling man. Gillson, president of the university from 1948 to 1954, not only championed the idea of the collection but also selected items to be purchased. While we have not yet come across documents in which Gillson explicitly describes his motivation, the record of his acquisitions suggests that his ideas about the collection 
developed over a relatively short period of time. ${ }^{25}$ According to T. Herman Keahey, "the earliest purchases made from 1949 to 1951 were mostly 'rather special' modern books, a total of twenty-five items. Later in 1951, it seems that Gillson's conception of both the size and nature of the collection had changed, and he began much more extensive purchases, and of much rarer materials."26 In the fiscal years of 1951-52 and 1952-53, Gillson purchased 169 books in addition to the twenty-one he had acquired in the previous two fiscal years. Although books were relatively inexpensive in the post-war years, his acquisitions were extensive and expensive, the equivalent of the sum of the average salary of three professors at the time. ${ }^{27}$

The question of how to pay for the collection came to a head in 1952, and it ultimately resulted in the formation of the collections as we know them today. As the number of invoices mounted, and thus the extent of Gillson's purchases became clear, F. W. Crawford, the university's comptroller, put increasing pressure on the president to use his own funds to pay for the books. Crawford's tone can be discerned in a memo entitled "LIBRARY" sent to Gillson on 17 June 1952:

The attached invoice is for a book that was ordered by you. I understand from $\mathrm{Mr}$ Bower that you are to take care of these invoices yourself. This is the third invoice that has been sent to you from this office. I will appreciate it if you will advise me when the matters have been straightened out with the suppliers, so that we will be able to get the liability off the books of the University. ${ }^{28}$

25. We are grateful that we have the assistance of Dr. Shelley Sweeney, Head of the Archives \& Special Collections at the University of Manitoba, who has made documents pertaining to the collections available to us as they become known to her; we are hopeful that more documents of this kind will come to light.

26. T. Herman Keahey, “The Brewers' Benefaction: Treasures from the Foam," Alumni Journal 52.4 (1992): 4-6, 5. In a letter dated 23 November 1992, Keahey regrets that his acknowledgement of Ruth May's work on the collections, particularly a paper she presented in April 1986 entitled "Books of a Special Character," was removed by the journal's editors. A draft of Keahey's paper in box 194-005, President's Papers UA 29, University of Manitoba, Archives \& Special Collections, includes this reference.

27. Keahey, “The Brewers' Benefaction."

28. F. W. Crawford to A. H. Gillson, 17 June 1952, box 194-005, President's Papers UA 29, University of Manitoba, Archives \& Special Collections. 
At some point in the next three weeks, Crawford was informed of the promised donation from the Manitoba Brewers' and Hotelmen's Welfare Fund. Nonetheless, he still worried about the money needed to cover what he was now describing in the title of his memos as "RARE AND EXPENSIVE BOOKS." In correspondence dated 5 July 1952, he informed Gillson that "Two members of the Board have told me that they are very anxious to get these invoices off the books and have them covered by a grant." ${ }^{29} \mathrm{He}$ expressed concern that the $\$ 10,000$ donation was insufficient to cover what he believed at that time was a total cost of $\$ 10,179.00$, and he asked Gillson for a suggestion about what should be done. By 30 September 1952, additional invoices had arrived, and Crawford seems to have made up his own mind about what should be done. He wrote to Gillson demanding that the outstanding amount, now \$2450.00, should be transferred "from your Research Account," and he asked that the transfers be made within the next two days. ${ }^{30}$ By November of 1952, it had become clear that Gillson's purchases for the two previous years amounted to $\$ 13,434,34 .^{31}$

Knowing that the cost of his purchases was in excess of the donation he had secured for their acquisition, Gillson asked head librarian Elizabeth Dafoe to create two lists. In her letter to the Comptroller, she refers to making a list of books in "the Gift Collection" and a "second list, those items which should be charged to the General Research Account." 32 It is true to say that the books in the Dysart Collection were carefully chosen to be "representative of the best book arts of scribes, printers, and illustrators over a span of six hundred years." ${ }^{33}$ It is also true to say that they were chosen very carefully because of their combined cost: its nine manuscripts and sixty printed books cost a combined

29. F. W. Crawford to A. H. Gillson, 5 July, 1952, box 194-005, President's Papers UA 29, University of Manitoba, Archives \& Special Collections.

30. F. W. Crawford to A. H. Gillson, 30 September 1952, box 194-005, President's Papers UA 29, University of Manitoba, Archives \& Special Collections.

31. The Comptroller has the amount at $\$ 13,395.59$ while Elizabeth Dafoe identifies the amount as $\$ 13,434.34$, a difference of $\$ 38.75$. Elizabeth Dafoe to F. W. Crawford, 12 November 1952, box 194-005, President's Papers UA 29, University of Manitoba, Archives \& Special Collections.

32. Elizabeth Dafoe to F. W. Crawford.

33. W. Royce Butler, The Dysart Memorial Collection of Rare Books and Manuscripts: An Exhibition Held at the Gallery 1.1.1., The University of Manitoba, 23 April-11 May 1973 (Winnipeg: University of Manitoba, 1973). 
total of $\$ 9,999.15$, just 85 cents short of the amount donated for their purchase. The books on the second list were also likely selected for their price: although there are one hundred of them on the list, their combined cost was $\$ 3,435.19 .{ }^{34}$ However, these books were also selected because they could more easily be classified as books acquired for research purposes in particular disciplines. The 1632 second folio of Shakespeare's works (which only cost \$229.50!) and 1632 edition of Bacon's Essays or counsels are listed under "English"; editions of the Bible printed by Barker in 1608, 1630, and 1631 (New Testament) are listed under "General"; and an Aldine edition of Livy printed in 1555 is listed under "Classics." Special mention must be made of R. T. H. Laennec's L'ausculation médiate (Paris, 1819), which is listed as "Medicine," and was purchased "at the President's request through Dr. Adamson. The understanding was it was to be placed in the Medical Library." ${ }^{35}$ This book is now found in the Neil John Maclean Health Sciences Library Rare Books Collection. ${ }^{36}$

The second list of books, entitled "Special Research Publications," accounts for all but twenty-one of the books that Keahey knew Gillson had acquired but that were not catalogued as part of the Dysart Collection. However, these twenty-one remaining titles appear on a draft of the "Special \& Research Publications" list completed in July 1952. All except one are struck through with the note 1950-51 beside them; the one exception is a facsimile of Blake's Jerusalem, which has the note 1949-50. As it turns out, these remaining volumes were not included in either the Dysart Collection or what became known as the second list because they were purchased in the previous two fiscal years.

34. A draft of this list complete to July 1952 and a final copy written in November 1952 are held in box 194-005, President's Papers UA 29, University of Manitoba, Archives \& Special Collections.

35. This instruction is printed in type at the top of a memo entitled "Rare Books ordered during May by President Gillson and Charged to SLE 403-97," box 194-005, President's Papers UA 29, University of Manitoba, Archives \& Special Collections.

36. Many of the books in the Dysart Collection and several of the books in the second list have been used in the past decade to supplement educational opportunities for the public and for students in several different courses (mainly in the Department of History and the Department of English, Film, and Theatre). We know that the books in the Dysart Collection were exhibited several times, for the catalogue in use today was created for an exhibition held from 23 April to 11 May 1973. In the foreword to the exhibition catalogue, Edward Doré states that "the educational value of these books cannot be over-emphasized," and we are currently attempting to determine whether these books were initially purchased for their educational value and if the public had access to them for this purpose in the first fifty years of the collection's existence. 
Ultimately, Dafoe's careful creation of both lists helped to ensure that the purchase of these books was completed. It therefore seems appropriate to speculate that the maker of the bookplate had her features in mind when creating the image of the seated figure receiving the book. Literally or figuratively, the scene in the book plate seems to dramatize the roles played by Gillson, who purchased the books and offered them to the university, and Dafoe, who ensured they would find a place in the library that now bears her name.

While the Dysart bookplate sheds some light on how and why so many manuscripts and rare books came to be located in Winnipeg, it also reminds us that there may be other costs associated with the process of translatio studii. The bison on the university crest acknowledges the indigenous history of the prairies, yet relegates it to an inert part of the background in order to make space for the scene of European learning being translated into the Canadian context. The crest implicitly recognizes the fact that the University of Manitoba is located on Treaty 1 territory but asks readers to see that territory as a place where the tastes represented and reinforced by European books should beor already have been-transposed. This bookplate reminds us that we must continue to think critically about the place of the books we study and their impact on our relationship with all people who live in that place. It is important that we continue to reflect critically upon the cultural, historical, and literary implications of their place in the prairies even as we celebrate their historical value. ${ }^{37}$ With this in mind, the following paragraphs explore several key ways in which the collection might help us to understand the place of books in the Renaissance and Reformation. This section does not attempt to enumerate all of the ways in which the collection might be used or even all of the books available. Instead, it draws on some of the work that has already been undertaken with the collections in order to invite scholars to begin thinking about new ways to work with these books.

One way that the University of Manitoba manuscripts help us to understand the place of books in the Renaissance and Reformation is by reminding us that books continued to be made in manuscript form throughout this period and that manuscripts frequently found a place in printed books. ${ }^{38}$ All but one

37. For a model for pursuing this work, see Migrations: Medieval Manuscripts in New Zealand, ed. Stephanie Hollis and Alexandra Barratt (Newcastle Upon Tyne: Cambridge Scholars, 2007).

38. William W. E. Slights argues for the importance of considering contemporary history as part of book history in "Back to the Future-Littorally: Annotating the Historical Page," The Future of the Page, ed. 
of the manuscripts in the Dysart Collection are arguably Renaissance productions, having been produced in the late fifteenth century or later. ${ }^{39}$ Dysart MSS 1 and 2 were made in the late fifteenth and early eighteenth centuries respectively. These two books remind us that it was expedient to make certain kinds of books by hand rather than to use a press. Both are large antiphonaries made so that they could be read by more than one person at a time. The fifteenthcentury antiphonary, Dysart MS 1, comes from the Abbey of St. Bartholomew near Ferrara, Italy; it is the largest book in the collection (335 mm x $470 \mathrm{~mm}$ ) and it contains a number of substantial illuminations. Dysart MS 2, the seventeenth-century antiphonary, is not quite so large (260 mm x $290 \mathrm{~mm}$ ), but it is legibly written in a large gothic script on high quality paper. Manuscript production remained the most efficient option for making books like this over three centuries.

Like Dysart MS 1, Dysart MS 6 was likely produced for local use in Ferrara: it consists of two leaves celebrating the office of its patron, Saint Maurelius. ${ }^{40}$ While the size of this bifolium would not have made printing impractical, the fact that this office was primarily celebrated locally would have made it inefficient to print copies, especially if they were to be as carefully decorated as this particular exemplar. Dysart MS 6 initially seems odd: it is a single bifolium that is self-sufficient but does not seem to have been meant to circulate independently. This suggests that it may have been made locally to circulate as an addition to a more widely circulated and standardized-even printed-missal. One of the printed books in the collection provides evidence for this practice. Dysart 31 is a copy of the Missale Augustense Speciale printed by Erhard Ratdolt (Augsburg, 1505). Through comparison with other versions of the text, Maria Gonzales has demonstrated that the version in our collection is a modified version of an earlier addition. ${ }^{41}$ It is even possible that Ratdolt modified this book by making changes to it in standing type. This book is remarkable in a number of ways: it reveals Ratdolt's mastery of colour printing and it also reveals the care

Peter Stoicheff and Andrew Taylor (Toronto: University of Toronto Press, 2004), 71-89.

39. Dysart MS 3 can be dated to the early thirteenth century.

40. There are a number of important images of Maurelius as well as reliquaries in the Museo della Cattedrale di Ferrara; see the Catalago generale (Ferrara: Fondazione Carife, Cassa di Risparmio di Ferrara, 2010).

41. Maria Gonzales undertook a comprehensive description of this book as part of an advanced undergraduate reading course. 
he took to ensure the book would last a long time, for the Canon of the Mass is printed on vellum and illuminated lavishly. It also incorporates a manuscript copy of the Officium Michaelis Archangeli written on the same paper stock as the rest of the book. The hand in which the office is written further conveys the sense that the addition was meant to be seen as an integrated part of the book as a whole, for it imitates the book's typeface. Examples like these remind us that manuscripts continued to find a place in Renaissance culture and books.

One other common way that medieval manuscripts found a place in Renaissance books was through the binding process. ${ }^{42}$ The three most striking examples of this practice in the University of Manitoba's collections employ earlier texts as a covering for the binding's exterior boards. Vitruvius Pollio's De Archetectura, printed in 1550, incorporates two fragments. ${ }^{43}$ The fragment on the cover records a prayer in a gothic hand; though this hand likely dates to the fourteenth or fifteenth century, the manuscript in which the prayer was written had likely become outdated by the time this book was printed. The fragment on the spine, which preserves a short section from Gregory's Homiliae in Evangelica, is much older. This fragment preserves one of the oldest writing specimens in the collection, a Carolingian hand likely dateable to the eleventh or twelfth century. The second example is a copy of Pantheologia by Rainerius de Pisis; ${ }^{44}$ its front and back covers are taken from the same choir book written in a gothic hand and including musical notation. The third example is Dysart 37, a copy of Oronce Finé's De rebus mathematicis printed in Paris in 1534, which is bound in parchment upon which an indecipherable Hebrew text appears. This last example demonstrates the extent to which parchment contracts over time, for the thin boards that support the parchment are now substantially curved. Several other fragments appear inside the bindings of several books, including one of the more recently acquired volumes in the collection, a copy of Quaestiones super tota philosophia naturali by Joannes de Magistris. ${ }^{45}$ The five small fragments that were used to strengthen this book's spine were likely drawn from a single book written either in a small Caroline minuscule or the

42. We thank Elizabeth-Anne Johnson for her help with this section. She is currently developing a descriptive catalogue of the fragments at the University of Manitoba; we are also grateful to her for her help with revisions to the article as a whole.

43. RBR NA 2515 V6 1550.

44. RBR Oversize BR 95 R34 1474 v.2.

45. RBR B 485 M33 1481. 
humanistic script that imitated it. Another fragment has been used for strength in Dysart 48, v. 1, a copy of the Biblia Latina cum Postillis Nicolai de Lyra printed by Octavianus Scotus in Venice in 1489. Thus the earliest printed books in the collection also provide evidence of the earliest samples of writing.

The scripts witnessed by these fragments provide a broad context for thinking about the place of scripts and fonts in the rest of the collection. For instance, the difficulty of distinguishing small samples of Caroline miniscule scripts from humanist scripts sheds light on the use of a humanist hand in Dysart MS 4, a late fifteenth-century copy of Julius Caesar's commentary on the Gallic and Civil Wars (Dysart MS 4). This book could have been printed; indeed, its layout and script more closely resemble Dysart 13, a copy of the Hypnerotomachia Poliphili printed by Aldus Manutius (Venice, 1499), than other contemporary manuscripts in the collection. Humanist scripts and typefaces like these intentionally imitated earlier models; they can therefore be understood as part of the process of translatio studii that the Dysart Collection bookplate invokes. They, too, attempt to reclaim an idealized Roman past in the form and content of a book. Dysart MS 4 contrasts sharply with a book like Dysart MS 5, a small (108 $\mathrm{mm}$ by $155 \mathrm{~mm}$ ) book that contains two works on Saint Jerome: St. Cyril's Epistola de Miraculi beati Hieronimi and St. Eusebius's Epistola de Morte gloriosissimi Hieronimi. This book, which is also a fifteenthcentury production, employs a Gothic script to convey spiritual matters. The contrast between Gothic scripts used for traditional religious material and humanist scripts used for humanist texts can be seen throughout the collection, extending into the age of print through the different content associated with black-letter and Roman typefaces. The University of Manitoba collections can help students understand why the Geneva Bible (1560) was set in Roman type whereas the Great Bible (1540) and Bishops' Bible (1568) were set in blackletter typefaces.

While the fragments in the collection suggest that manuscripts were sometimes more valuable for the strength of their material than for their content, the remaining manuscripts reveal the continuity of manuscript production throughout the Renaissance. Dysart MSS 7-9 and the most recently acquired manuscript in the collection help us to understand the way that manuscripts continued to function in the legal realm. Dysart MS 7 is a doctor's diploma presented to Gaudentius Carnerius. Betty Braaksma's extensive research has shown that while the text is a boilerplate copy of a degree, the elaborate decoration in 
this particular diploma was likely bespoke, designed specifically with its holder in mind. This can clearly be seen by users of the University of Manitoba's collections thanks to Braaksma's donation of a newly acquired diploma. ${ }^{46}$ Dysart MSS 8 and 9 are both legal documents issued under King Philip II of Spain. Dysart MS 8 is a letter written in engrossing script confirming the nobility of Don Gaspar de Gauna; ${ }^{47}$ Dysart MS 9 is a document granting the duties on all sales in six Spanish towns to Don Henrique de Guzman. Both manuscripts are lavishly decorated and marked to prevent forgery.

The Pomianyk of Horodysche donated by Professor Rudnyckyj reveals another purpose for which manuscripts continued to be used throughout the Renaissance and Reformation. As mentioned above, this book is a register of names of the deceased compiled between 1484 and 1737. It has quite an eventful history:

It was discovered in 1902 in an old wooden church believed to be the remains of the once famous monastery in the village of Horodyshche in Volhynia in Western Ukraine. It was purchased by Professor Rudnycknyj in 1951 from the family of the original discoverer, Oleksandr Kolessa (1867-1945), a distinguished Slavist at the Ukrainian Free Academy in Prague. The exceedingly rare cyrillic manuscript is also one of the earliest written documents ever found issued by Ukrainian Monasteries. Since the majority of monasteries in this area are Ukrainian Orthodox, it is assumed that the list was established by that denomination, rather than by Ukrainian Catholic churches. ${ }^{48}$

Professor Rudnyckyj has edited a facsimile of this manuscript, which can be accessed at the University of Toronto under the title Pamianyk Horodyshche. This book has already been the subject of a number of scholarly studies, though

46. A call number has yet to be assigned to this book. Those interested in examining it can inquire at the University of Manitoba's Archives \& Special Collections.

47. For an example of this kind of engrossing script, see D. C. Greetham, Textual Scholarship: An Introduction (New York: Garland, 1994), 206.

48. University of Manitoba Libraries, "Horodysche Pomianyk," Rare Books and Manuscript Collections, 13 March 2014, http://umanitoba.ca/libraries/archives/collections/type/rarebooks/bison/bis_slavMss1. html. 
more work could certainly be done to explore its significance historically as well as to the community today. ${ }^{49}$

The University of Manitoba's collections allow us to explore the place of manuscripts in the Renaissance and Reformation in more conventional ways as well. The Dysart Collection provides insight into the location of early printers. It includes books printed in Augsburg, Mainz, Nuremberg, Paris, Venice, and London by printers like Johann Amberbach (Dysart 47), John Day (38), Adam Islip (51), Nicholas Jenson (17), Anton Koberger (19, 21, and 48), Aldus Manutius (13, 38, 43, 45), Erhard Ratdolt (10, 20, 31), Peter Schoeffer (11), Octavianus Scotus (48), Georg Stuchs (12), Simon Vostre (26), Günther Zainer (14), and Ulrich Zell (18), among others. These texts provide samples of the range of typefaces and techniques that could be used to modify the appearance of books quite substantially. It is difficult to identify only a few highlights here, but several of the books do stand out. Dysart 11, an early copy of the Cronecken der Sassen by Peter Schoeffer (Mainz 1492), is particularly impressive for its use of woodcuts and typography. Dysart 16, Bämler's edition of Jacobus de Voragine's Legenda Aurea (Augsburg, 1477), merits further consideration for its use of Gothic type, the repetition and variation in its woodcuts, and its extensive hand-written rubrication, which can be dated to 1481. Many of Jenson's technical innovations are evident in Dysart 17, his edition of Pliny's Historia naturalis (Venice, 1472).$^{50}$ As noted at the beginning of this article, Dysart 22, 23, and 24 present three different versions of Jakob Locher's Stultifera nauis; the last of these contains both Locher's Latin version and Barclay's English translation of his work, and it may have been printed by separate printers. ${ }^{51}$ Dysart 25 provides an intriguing copy of $\mathrm{La}$ Metamorphose d'Ovide figuree (Lyon, 1564). There are several religious books of various kinds, including Dysart 30, a book of devotions (Augsburg, 1520),

49. Oleksandr Kolessa, Rozslidy i vydannia slovianskykh pamiatok apokryfichnoi literatury (1930); Iraida Irene Tarnawecky, "Anthroponymy in the Pomianyk of Horodyšče” (master’s thesis, University of Manitoba, 1964) and Anthroponymy in the Pomianyk of Horody̌̌če, Onomastica (Ukrainian Free Academy of Sciences, 1965).

50. For more on Jenson's innovation, see David R. Carlson, "Nicholas Jenson and the Form of the Renaissance Printed Page," The Future of the Page, ed. Peter Stoicheff and Andrew Taylor (Toronto: University of Toronto Press, 2004), 90-110.

51. Lyle Ford makes this argument on the basis of paper stock and typeface evidence in an unpublished paper written in 2006. 
the aforementioned Dysart 31, the Missale Augustense Speciale (Augsburg, 1505), and the significant fourth edition of John Foxe's Actes and Monuments (London, 1583). There are also a number of literary texts: Dysart 40 is an early Venetian edition of Petrarch (1515); Dysart 29 (1585) and Dysart 40 (1515) are early Venetian editions of Boccaccio and Petrarch respectively; Dysart 51 is Speght's important second edition of Chaucer (1602).

Dysart 21, Koberger's printing of the Nuremberg Chronicle, provides a remarkable opportunity for thinking about how collections across the prairies might be used together to develop a comparative study. Eventually, such a study might be undertaken virtually, using tools like the digital facsimile of the copy of the Nuremberg Chronicle in Wilcox, Saskatchewan. ${ }^{52}$ In the meantime, scholars may make a physical journey across the prairies to see the copies in Winnipeg and Edmonton as well. The range of bibles in prairie collections means that many aspects of research into the Bible as a book or the history of the Bible in English could be undertaken in the prairies. There are many other opportunities for scholars who are willing to explore these collections in aggregate. ${ }^{53} \mathrm{~A}$ unified descriptive catalogue of these collections and the production of digital resources to enhance their study will help students and scholars alike to recognize the potential for the study of Renaissance and Reformation books on the Canadian prairies, encouraging scholars to explore what distinguishes these collections from others in post-colonial contexts. As Christopher de Hamel points out in "Medieval Manuscripts and New Zealand," libraries in the "New World" do not look much like "Old World" libraries of the medieval or early modern periods, but they can tell us a great deal about the taste of their collectors and the availability of books at the time of their formation. ${ }^{54}$ By providing the resources to study prairie collections

52. See The Nuremberg Chronicle at the Athol Murray College of Notre Dame, Wilcox, Saskatchewan, website, 17 March 2014, https://drc.usask.ca/projects/nuremberg/doku.php/start. The authors of this article are working with each other and with those responsible for libraries on the prairies to seek funding to develop digital resources for the study of these books, including the digitization of many of these items.

53. For instance, one could replicate much of the evidence provided in Andrew Pettegree's The Book in the Renaissance (New Haven, CT: Yale University Press, 2010) by drawing only on books available in prairie collections.

54. See Christopher de Hamel, "Medieval Manuscripts and New Zealand," Migrations: Medieval Manuscripts in New Zealand, ed. Stephanie Hollis and Alexandra Barratt (Newcastle upon Tyne: 
individually and in aggregate, we hope to encourage students and scholars to learn more about book history as well as the role these books might have played in the history of the prairies.

\section{Conclusion}

The prairie collections reveal that those who have busied themselves to "haue store" of books on the prairies were no fools. They understood that the value of the books they were collecting was to be found in the "wisedome" they might offer. For some, the wisdom to be found in books was clearly spiritual in nature. For others, it was historical or cultural. There is still much to learn from these books. They still provide spiritual, historical, and cultural knowledge, yet they offer up another kind of knowledge as well: namely, insight into the way in which books shape the history of the places where they are found. The fact that these books must be found before they can reveal very much of anything is not a point lightly to be dismissed. The surprise most people experience when hearing about these collections for the first time suggests that there is much work to do to ensure that students, scholars, and members of our community know how to find them and can understand what they mean. 


\section{Appendix}

Contact information for collections described in this article

\section{Saskatchewan}

\section{The Peter Bietenholz Rare Books Collection}

Location: Special Collections

Address: Murray Library, 3 Campus Drive, Saskatoon SK S7N 5A4

Email: ua.sc@usask.ca

Web: http://library2.usask.ca/bietenholz/node/5

Telephone: 306-966-6029

\section{Father Athol Murray Rare Book Collection}

Location: Athol Murray College of Notre Dame Archive and Museum, Address: 49 Main Street, Wilcox, SK S0G 5E0

Telephone: 306-732-2080 ext. 121

Web: https://drc.usask.ca/projects/mepb/doku.php/start

\section{Shannon Library, St. Thomas More College}

Address: 1437 College Drive, Saskatoon, SK S7N 0W6

Telephone: 306-966-8900 Toll Free: 1-800-667-2019

Web: http://stmcollege.ca/library/

\section{Theological Union Libraries, University of Saskatchewan}

Location and telephone: Consult the web address for the several libraries. Email: STU.Libraries@usask.ca

Web: http://reindex.net/STU/rss/Portal.php

\section{Manitoba}

\section{Walter Loewen Collection}

Location: Mennonite Heritage Centre Archives, Canadian Mennonite University

Address: 600 Shaftesbury Blvd. Winnipeg, MB R3P 2N2

Phone: 204-888-6781 Fax: 204-831-5675

Email: library@cmu.ca

Web: http://www.mennonitechurch.ca/programs/archives/ 


\section{St John's College Collection}

Location: Archives \& Special Collections, University of Manitoba Address: 330 Elizabeth Dafoe Library, University of Manitoba, Winnipeg, MB R3T 2N2

Phone: 204-474-9986 Fax: 204-474-7913

Email: archives@umanitoba.ca

Web: http://umanitoba.ca/libraries/units/archives/

\section{The Dysart Memorial Collection}

Location: Archives \& Special Collections, University of Manitoba Address: 330 Elizabeth Dafoe Library, University of Manitoba, Winnipeg, MB R3T 2N2

Phone: 204-474-9986 Fax: 474-7913

Email: archives@umanitoba.ca

Web: http://umanitoba.ca/libraries/units/archives/media/dysart_catalogue.pdf

\section{Archives \& Special Collections, University of Manitoba}

Address: 330 Elizabeth Dafoe Library, University of Manitoba, Winnipeg, MB R3T 2N2

Phone: 204-474-9986 Fax: 204-474-7913

Email: archives@umanitoba.ca

Web: http://umanitoba.ca/libraries/units/archives/ 